\title{
HUBUNGAN KAUSALITAS NILAI TUKAR RUPIAH TERHADAP DOLLAR AMERIKA SERIKAT, JUMLAH UANG BEREDAR DAN TINGKAT INFLASI
}

\author{
NADYA RISNA PUTRI, HAZMIRA YOZZA, DODI DEVIANTO \\ Program Studi S1 Matematika, \\ Fakultas Matematika dan Ilmu Pengetahuan Alam, Universitas Andalas, \\ Kampus Unand Limau Manis, Padang, Indonesia \\ email : nadyarisnaputri@gmail.com
}

Diterima 9 Maret 2019 Direvisi 7 April 2019 Dipublikasikan 7 Mei 2019

\begin{abstract}
Abstrak. Penelitian ini dilakukan untuk mengetahui hubungan kausalitas antara nilai tukar (kurs) rupiah terhadap dolar Amerika Serikat, jumlah uang beredar dan tingkat inflasi. Metode penelitian yang digunakan yaitu uji kausalitas Granger. Kemudian untuk mendapatkan hasil estimasi, dilakukan pengujian stasioneritas dengan menggunakan uji Augmented Dickey-Fuller (ADF) dan transformasi Box-Cox. Data yang digunakan pada penelitian ini yaitu data runtun waktu dari tahun 2003 sampai dengan tahun 2018. Hasil penelitian ini menunjukan bahwa: (1) terdapat hubungan kausalitas satu arah pada jumlah uang beredar dengan tingkat inflasi serta pada nilai tukar rupiah terhadap dolar Amerika Serikat dengan tingkat inflasi, (2) terdapat hubungan kausalitas dua arah pada nilai tukar rupiah terhadap dolar Amerika Serikat dengan jumlah uang beredar.
\end{abstract}

Kata Kunci: Augmented Dickey-Fuller, kausalitas Granger

\section{Pendahuluan}

Negara berkembang seperti Indonesia memiliki struktur perekonomian yang cenderung masih sangat rentan terhadap adanya goncangan pada kestabilan kegiatan perekonomian. Salah satu goncangan tersebut adalah inflasi. Inflasi merupakan proses kenaikan harga-harga yang berpengaruh dalam suatu perekonomian. Inflasi juga merupakan proses menurunnya nilai mata uang secara kontinu. Menurut Thomas Arifin [2], inflasi yang stabil merupakan persyaratan pertumbuhan ekonomi yang akan memberikan keuntungan terhadap kesejahteraan masyarakat.

Inflasi dapat dipengaruhi oleh beberapa hal. Salah satunya yaitu nilai tukar mata uang. Nilai tukar mata uang atau kurs adalah perbandingan nilai mata uang suatu negara terhadap nilai mata uang negara lainnya. Kurs rupiah terhadap dolar Amerika Serikat memainkan peran sentral dalam perdagangan internasional. Menurut Agustin [1], perbedaan tingkat inflasi antar negara juga dapat mempengaruhi nilai tukar mata uangnya.

Inflasi secara umum juga dapat terjadi karena banyaknya jumlah uang beredar melebihi jumlah yang dibutuhkan. Jumlah uang beredar merupakan jumlah uang 
yang ada dan dapat digunakan untuk melakukan berbagai macam transaksi oleh masyarakat dalam perekonomian. Menurut Triyono [10], jumlah uang beredar yang berlebih pada sistem perekonomian dapat memberikan tekanan pada nilai tukar mata uang. Naiknya jumlah uang akan menaikan harga-harga, sekaligus menaikan harga valuta asing yang diukur dengan uang domestik.

Tingkat inflasi, kurs mata uang dan jumlah uang beredar di Indonesia memiliki dampak yang cukup besar bagi perkembangan perekonomian negara. Peran pemerintah dalam merencanakan, mengambil serta mengevaluasi suatu kebijakan perekonomian yang dapat mempengaruhi hal-hal tersebut sangat diperlukan. Oleh karena itu, hubungan tingkat inflasi, nilai tukar mata uang dan jumlah uang beredar merupakan topik yang menarik untuk dibahas.

Kausalitas Granger merupakan salah satu analisis untuk melihat hubungan sebab akibat pada data runtun waktu. Tingkat inflasi, nilai tukar mata uang dan jumlah uang beredar merupakan data runtun waktu. Oleh karena itu, untuk melihat hubungan sebab akibat pada data tingkat inflasi, nilai tukar mata uang dan jumlah uang beredar digunakan metode kausalitas Granger.

\section{Landasan Teori}

\subsection{Istilah dalam Keuangan}

Berikut dijelaskan istilah dalam keuangan:

(1) Nilai Tukar (Kurs) Mata Uang Rupiah terhadap Dolar Amerika Serikat. Kurs merupakan harga sebuah mata uang suatu negara yang dinyatakan dalam mata uang negara lainnya. Nilai tukar (kurs) mata uang rupiah terhadap dolar Amerika Serikat memainkan peran sentral dalam perdagangan internasional [8].

(2) Jumlah Uang Beredar.

Jumlah uang beredar merupakan jumlah uang yang ada dan dapat digunakan untuk melakukan berbagai macam transaksi oleh masyarakat dalam perekonomian. Jumlah uang beredar didefinisikan dalam dua pengertian yaitu [7]:

(a) Uang beredar dalam arti sempit $\left(M_{1}\right)$

Uang beredar dalam arti sempit didefinisikan sebagai jumlah uang kartal $(C)$ dan uang giral $(D D)$.

(b) Uang beredar dalam arti luas $\left(M_{2}\right)$

Uang beredar dalam arti luas didefinisikan sebagai jumlah uang beredar meliputi $M_{1}$, uang kuasi (simpanan berjangka dalam rupiah, valas $(T D)$, giro dalam valuta asing dan tabungan) dan surat berharga yang dikeluarkan oleh sistem moneter $(S D)$.

(3) Tingkat Inflasi.

Inflasi adalah suatu proses kenaikan harga-harga. Tingkat inflasi dapat dihitung sebagai berikut [6]:

$$
L I_{t}=\frac{I H K_{t}-I H K_{t-1}}{I H K_{t-1}} \times 100 \%
$$

dengan $L I_{t}=$ Tingkat inflasi pada waktu ke- $t, I H K_{t}=$ Indeks Harga Konsumen pada waktu ke- $t$, dan $I H K_{t-1}=$ Indeks Harga Konsumen pada waktu ke- $(t-1)$. 


\subsection{Data dan Analisis Runtun Waktu (Time Series)}

Himpunan hasil observasi terhadap suatu variabel yang diambil secara beruntun atau terurut berdasarkan interval waktu yang tetap disebut data runtun waktu (time series). Analisis sekumpulan data yang menjelaskan dan mengukur perubahan serta perkembangan data selama satu periode waktu yang lampau disebut dengan analisis data runtun waktu [11].

\subsection{Stasioneritas Data}

Sekumpulan data dinyatakan stasioner jika nilai rata-rata dan varian dari data runtun waktu tersebut tidak mengalami perubahan secara sistematik sepanjang waktu [4]. Sebagian ahli menyatakan kondisi ini sebagai kondisi dengan rata-rata dan variannya konstan.

\subsubsection{Uji Augmented Dickey-Fuller (ADF)}

Salah satu cara menguji kestasioneritasan dalam mean pada data runtun waktu adalah menggunakan uji akar unit (unit roots test). Untuk melihat keberadaan akar unit dalam model dapat digunakan persamaan berikut:

$$
\Delta Y_{t}=\alpha+\delta t+\beta Y_{t-1}+\sum_{i=1}^{k} \phi_{i} \Delta Y_{t-1}+e_{t}
$$

dimana $e_{t}$ adalah error yang white noise yaitu error yang memiliki rataan dan ragam yang konstan serta saling bebas (tidak berautokorelasi), $\Delta Y_{t}=Y_{t}-Y_{t-1}$, $\beta=\alpha-1$ dan adalah $\Delta$ operator first-difference (bagian ini akan dibahas pada subbab selanjutnya).

Hipotesis pada uji ADF adalah sebagai berikut [6]:

$H_{0}: \beta=0, Y_{t}$ memiliki akar unit atau tidak stasioner,

$H_{1}: \beta \neq 0, Y_{t}$ tidak memiliki akar unit atau stasioner.

Statistik uji yang digunakan adalah statistik $t$ dengan

$$
t=\frac{\hat{\beta}}{S E(\hat{\beta})}
$$

Kesimpulan diambil berdasarkan kriteria uji bahwa $H_{0}$ ditolak jika nilai statistik uji memiliki nilai lebih kecil daripada nilai kritis McKinnon.

\subsubsection{Proses Pembeda (Differencing)}

Proses pembeda merupakan suatu metode yang digunakan untuk membuat data runtun waktu yang non-stasioner dalam mean menjadi data runtun waktu yang stasioner. Proses ini dilakukan dengan cara mengurangi data pada periode bersangkutan dengan data periode sebelumnya. Proses pembeda sangat tepat digambarkan dengan operator shift mundur (backward shift) sebagai berikut [5]:

$$
B Y_{t}=Y_{t-1} .
$$


Apabila suatu data runtun waktu tidak stasioner, maka data tersebut dapat dibuat lebih mendekati stasioner dengan melakukan pembedaan pertama (first difference).

$$
\Delta Y_{t}=Y_{t}-Y_{t-1}
$$

Dengan menggunakan operator shift mundur, persamaan (2.5) dapat ditulis menjadi:

$$
\Delta Y_{t}=Y_{t}-B Y_{t}=(1-B) Y_{t}
$$

dimana $(1-B)$ menyatakan pembedaan pertama.

Menghitung pembedaan bertujuan untuk mencapai stasioneritas dan secara umum pembedaan orde ke-n yang dilakukan untuk mencapai stasioneritas dapat ditulis sebagai berikut:

$$
(1-B)^{n} Y_{t}
$$

\subsubsection{Transformasi Data}

Ketidakstasioneran data pada variannya dapat dihilangkan dengan melakukan transformasi Box-Cox melalui pemilihan dan penetapan nilai $\lambda$. Secara umum, transformasi Box-Cox yang digunakan dinyatakan sebagai berikut [3]:

$$
T\left(Y_{t}\right)=\left(Y_{t}\right)^{(\lambda)}= \begin{cases}\frac{\left(Y_{t}\right)^{(\lambda)}-1}{\lambda} & ; \lambda \neq 0, \\ \ln \left(Y_{t}\right) & ; \lambda=0,\end{cases}
$$

Nilai $\lambda$ yang dipilih yaitu nilai $\lambda$ yang dapat meminimalkan nilai $S(\lambda)$ dan dirumuskan sebagai berikut:

$$
S(\lambda)=\ln \sum_{t-1}^{N}\left(Y_{t}(\lambda)-\bar{Y}_{t}(\lambda)\right)^{2}-\frac{2}{N}(\lambda-1) \sum_{t-1}^{N} \ln Y_{t}
$$

dengan $Y_{t}(\lambda)$ : nilai data yang telah ditransformasi, $\bar{Y}_{t}(\lambda)$ : rata-rata dari $Y_{t}$, dan $N$ : banyaknya data.

\subsection{Uji Kausalitas Granger}

Uji kausalitas digunakan untuk mengetahui diantara dua variabel yang berhubungan, variabel mana yang menyebabkan variabel lain berubah. Diantara beberapa metode pengujian yang ada, metode Granger's Causality yang paling populer. Pada pengujian ini dapat dilihat apakah suatu variabel mempunyai hubungan dua arah atau hanya satu arah saja.

Model dasar uji kausalitas adalah [5]:

$$
\begin{aligned}
Y_{t} & =\sum_{i=1}^{m} a_{i} Y_{t-i}+\sum_{j=1}^{m} b_{j} X_{t-j}+v_{t} \\
X_{t} & =\sum_{j=1}^{m} c_{j} X_{t-j}+\sum_{i=1}^{m} d_{i} Y_{t-i}+\mu_{t}
\end{aligned}
$$


dengan $X_{t}=$ variabel $X$ pada waktu ke- $t, Y_{t}=$ variabel $Y$ pada waktu ke- $t, m$ $=$ jumlah $l a g, \mu$ dan $v_{t}=$ variabel pengganggu pada waktu ke- $t, a, b, c$ dan $d=$ koefisien masing-masing variabel diasumsikan bahwa $\mu_{t}$ dan $v_{t}$ tidak berkorelasi.

Hipotesis pada uji kausalitas adalah sebagai berikut.

$H_{0}$ : suatu variabel tidak menyebabkan atau mempengaruhi satu variabel lainnya, $H_{1}$ : suatu variabel menyebabkan atau mempengaruhi satu variabel lainnya.

Statistik uji yang digunakan adalah statistik uji F. Kriteria uji yang digunakan yaitu $H_{0}$ ditolak jika nilai statistik $\mathrm{F}>$ nilai $\mathrm{F}$ tabel. Jika seluruh variabel memiliki nilai F-statistik lebih besar dari nilai F-tabel pada tingkat signifikan tertentu, maka kedua variabel tersebut memiliki kausalitas dua arah.

\section{Data dan Metode}

\subsection{Data}

Pada penelitian akan dibahas hubungan nilai tukar rupiah dengan dolar Amerika Serikat, jumlah uang beredar dan tingkat inflasi menggunakan kausalitas Granger. Data yang digunakan adalah data sekunder bulanan yang terdiri dari data bulanan nilai tukar rupiah terhadap dolar Amerika Serikat tahun 2003-2018, data jumlah uang beredar tahun 2003-2018 dan data inflasi tahun 2003-2018 yang diperoleh dari publikasi pada situs resmi Bank Indonesia dan Kementrian Perdagangan Republik Indonesia.

\subsection{Metode}

Langkah-langkah yang dilakukan pada penelitian ini adalah:

(1) Melakukan transformasi Box-Cox jika data tidak stasioner dalam varian.

(2) Melakukan uji stasioner dalam mean pada masing-masing variabel dengan menggunakan uji Augmented Dickey-Fuller (ADF). Jika variabel tidak stasioner dalam mean maka dilakukan proses diferensi hingga seluruh variabel stasioner.

(3) Melihat hubungan tingkat inflasi dengan nilai tukar rupiah dengan dolar Amerika Serikat dan jumlah uang beredar menggunakan uji kausalitas.

\section{Hasil dan Pembahasan}

\subsection{Transformasi Data}

Sebelum dilakukan pengolahan data, terlebih dahulu dilihat kestasioneran dalam varian pada masing- masing variabel. Jika data masing-masing variabel tidak stasioner dilakukan transformasi variabel yang bertujuan untuk menstasionerkan varian data. Transformasi data dilakukan berdasarkan nilai $\lambda$ pada masing-masing data. Nilai $\lambda$ dapat diperoleh dengan menggunakan bantuan diagram Box-Cox.

(1) Transformasi Box-Cox Nilai Tukar Rupiah terhadap Dolar Amerika Serikat. Pada Gambar 1(a) terlihat bahwa nilai rounded value atau $\lambda$ adalah $-3,00$ sehingga perlu dilakukan transformasi pada data nilai tukar rupiah. Transformasi 
yang digunakan yaitu $\frac{1}{K U R S_{t}^{3}}$. Setelah ditransformasi, Gambar 1 (b) menunjukan nilai rounded value adalah 1,00 dengan kata lain data nilai tukar rupiah sudah stasioner dalam varians.

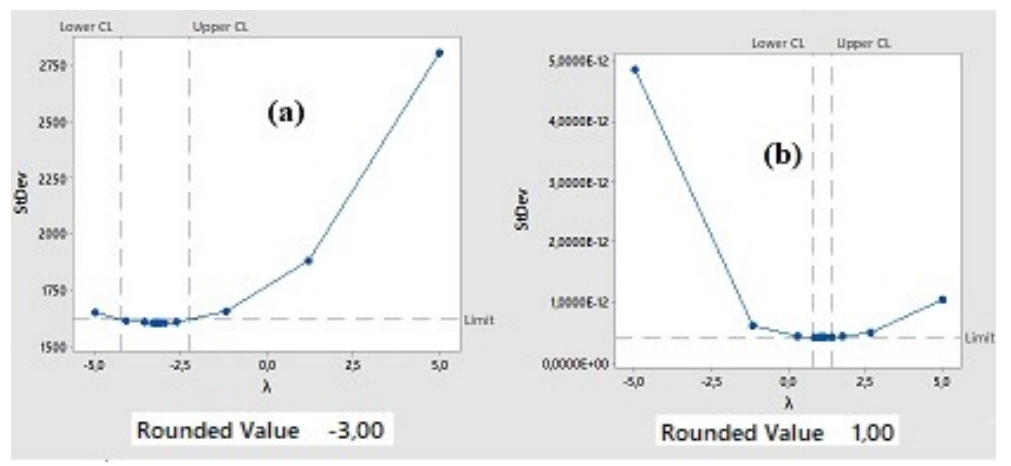

Gambar 1. (a) Diagram Box-Cox Nilai Tukar Rupiah terhadap Dolar Amerika Serikat, (b) Diagram Box-Cox Hasil Transformasi Nilai Tukar Rupiah terhadap Dolar Amerika Serikat

(2) Transformasi Box-Cox Jumlah Uang Beredar

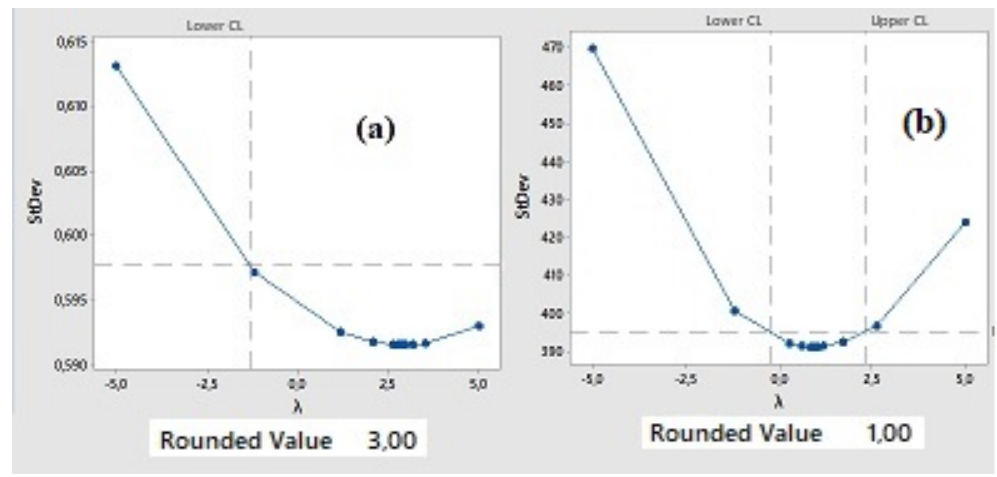

Gambar 2. (a) Diagram Box-Cox Jumlah Uang Beredar, (b) Diagram Box-Cox Hasil Transformasi Jumlah Uang Beredar

Diagram Box-Cox untuk data jumlah uang beredar pada Gambar 2 (a) memberikan nilai rounded value yaitu 3,00 yang berarti data jumlah uang beredar tidak stasioner terhadap varian, sehingga dilakukan transformasi Box-Cox untuk data jumlah uang beredar. Dengan melakukan transformasi $\ln \left(J U B_{t}^{3}\right)$ diperoleh nilai rounded value yaitu 1, 00 (Gambar 2(b)), dengan kata lain dapat disimpulkan bahwa varian data jumlah uang beredar sudah stasioner.

(3) Transformasi Box-Cox Tingkat Inflasi 


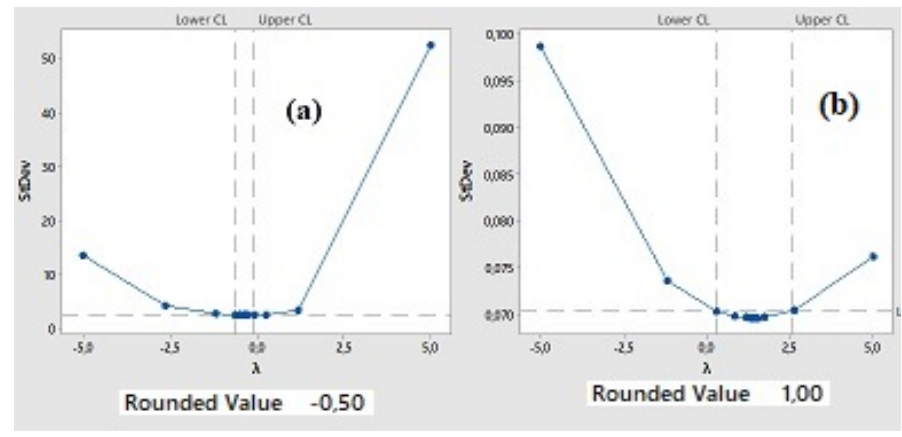

Gambar 3. (a) Diagram Box-Cox Tingkat Inflasi, (b) Diagram Box-Cox Hasil Transformasi Tingkat Inflasi

Berdasarkan pengujian pada kestasioneran varian dengan menggunakan transformasi Box-Cox diperoleh bahwa variabel tingkat inflasi memiliki nilai rounded value sebesar -0,50 (Gambar 3(a)) sehingga dapat disimpulkan variabel tingkat inflasi tidak stasioner dalam varian. Selanjutnya dilakukan proses transformasi pada variabel tingkat inflasi dengan bentuk $\sqrt{\frac{1}{\sqrt{I N F_{t}}}}$. Setelah dilakukan transformasi pada variabel tingkat inflasi didapatkan nilai rounded value sebesar 1,00 (Gambar 3(b)). Hal ini menandakan variabel tingkat inflasi sudah stasioner dalam varian, sehingga tidak perlu dilakukan transformasi kembali.

\subsection{Uji Stasioneritas Data}

Untuk memenuhi salah satu syarat dalam analisis runtun waktu, maka perlu terlebih dahulu dilakukan uji stasioneritas. Pada penelitian ini, uji stasioneritas yang digunakan yaitu menggunakan uji akar-akar unit dengan metode Augmented Dickey Fuller Test (ADF). Berikut hasil pengujian stasioneritas data asli masing-masing variabel menggunakan Eviews 10:

Tabel 1. Hasil Uji Stasioneritas Data

\begin{tabular}{|l|c|l|}
\hline Variabel & t-Statistik & Kesimpulan \\
\hline Nilai Tukar Rupiah & $-1,435001$ & Tidak Stasioner \\
Jumlah Uang Beredar & 1,392730 & Tidak Stasioner \\
Tingkat Inflasi & 0,292374 & Tidak Stasioner \\
\hline
\end{tabular}

Keterangan $t_{0,05 ; 250}=-1,942$

Berdasarkan Tabel 1 di atas, nilai t-statistik masing-masing variabel kurang dari nilai kritis maka kriteria pengujian yang diambil yaitu tidak tolak $H_{0}$ atau dengan kata lain variabel nilai tukar Rupiah terhadap dolar Amerika Serikat, jumlah uang beredar, dan tingkat inflasi tidak stasioner pada level sehingga perlu dilakukan proses pembeda. Hasil uji stasioneritas data diferensi dapat dilihat pada Tabel 2. 
Tabel 2. Hasil Uji Stasioneritas Data Tingkat Diferensi 1

\begin{tabular}{|l|c|l|}
\hline Variabel & t-Statistik & Kesimpulan \\
\hline Nilai Tukar Rupiah & $-2,524021$ & Stasioner \\
Jumlah Uang Beredar & $-0,454701$ & Tidak stasioner \\
Tingkat Inflasi & $-6,266021$ & Stasioner \\
\hline
\end{tabular}

Keterangan $t_{0,05 ; 250}=-1,942$

Berdasarkan Tabel 2, variabel nilai tukar rupiah telah stasioner pada nilai kritis $5 \%$ demikian juga dengan variabel tingkat inflasi sudah stasioner karena nilai tstatistiknya kurang dari nilai kritis. Namun, nilai t-statistik variabel jumlah uang beredar masih lebih besar dari nilai kritis, maka variabel jumlah uang beredar belum stasioner sehingga perlu dilakukan proses pembeda lagi. Hasil uji stasioneritas data diferensi 2 pada variabel jumlah uang beredar dapat dilihat pada Tabel 3.

Tabel 3. Hasil Uji Stasioneritas Data Jumlah Uang Beredar Tingkat Diferensi 2

\begin{tabular}{|l|c|l|}
\hline Variabel & t-Statistik & Kesimpulan \\
\hline Jumlah Uang Beredar & $-8,995115$ & Stasioner \\
\hline
\end{tabular}

Keterangan $t_{0,05 ; 250}=-1,942$

Berdasarkan hasil pengujian pada Tabel 2 dan Tabel 3, maka variabel tingkat inflasi dan nilai tukar rupiah stasioner pada derajat diferensi 1 sedangkan variabel jumlah uang beredar stasioner pada derajat diferensi 2. Pada pengolahan data selanjutnya digunakan data nilai tukar rupiah, jumlah uang beredar dan tingkat inflasi yang telah didiferensi.

\subsection{Uji Kausalitas Granger}

Uji kausalitas Granger merupakan suatu metode analisis untuk melihat hubungan kausalitas atau hubungan sebab-akibat suatu variabel terhadap variabel lain. Pada penelitian ini, akan dilihat bagaimana hubungan sebab-akibat dari tingkat inflasi, jumlah uang beredar dan nilai tukar Rupiah terhadap Dolar Amerika Serikat. Berikut hasil hubungan kausalitas dari masing-masing variabel.

(1) Hubungan kausalitas jumlah uang beredar dengan inflasi.

Hasil pengujian hubungan kausalitas antara variabel jumlah uang beredar dengan variabel tingkat inflasi disajikan pada Tabel 4. Berdasarkan Tabel 4 diperoleh bahwa nilai F-statistik $>$ dari F-tabel pada $H_{0}$ : Jumlah Uang Beredar tidak menyebabkan Inflasi, sehingga $H_{0}$ ditolak dan dapat disimpulkan bahwa variabel jumlah uang beredar memiliki hubungan kausalitas dengan variabel tingkat inflasi. Namun, sebaliknya pada $H_{0}$ : Inflasi tidak menyebabkan Jumlah Uang Beredar. Berdasarkan kedua hipotesis tersebut dapat disimpulkan hubungan kausalitas terjadi satu arah dari variabel jumlah uang beredar terhadap variabel inflasi. 
Tabel 4. Hasil Uji Kausalitas Antara Jumlah Uang Beredar dengan Inflasi

\begin{tabular}{|c|c|l|}
\hline Null Hypothesis & F-Statistic & Kesimpulan \\
\hline Jumlah Uang Beredar tidak menyebabkan Inflasi & 2,48830 & tolak $H_{0}$ \\
Inflasi tidak menyebabkan Jumlah Uang Beredar & 0,27939 & terima $H_{0}$ \\
\hline
\end{tabular}

Keterangan $F_{0,05 ; 60,120}=1,43$

(2) Hubungan kausalitas nilai tukar Rupiah dengan inflasi.

Hasil pengujian hubungan kausalitas antara variabel nilai tukar Rupiah dengan variabel inflasi disajikan pada Tabel 5 .

Tabel 5. Hasil Uji Kausalitas Antara Nilai Tukar Rupiah dengan Inflasi

\begin{tabular}{|l|c|l|}
\hline \multicolumn{1}{|c|}{ Null Hypothesis } & F-Statistic & Kesimpulan \\
\hline Nilai tukar Rupiah tidak menyebabkan inflasi & 3,64479 & tolak $H_{0}$ \\
Inflasi tidak menyebabkan nilai tukar Rupiah & 0,45837 & Terima $H_{0}$ \\
\hline
\end{tabular}

Keterangan $F_{0,05 ; 60,120}=1,43$

Berdasarkan Tabel 5 diperoleh bahwa nilai F-statistik > dari F-tabel pada $H_{0}$ : Nilai tukar Rupiah tidak menyebabkan inflasi, sehingga $H_{0}$ ditolak dan dapat disimpulkan bahwa variabel nilai tukar Rupiah memiliki hubungan kausalitas dengan variabel tingkat inflasi. Namun, sebaliknya pada $H_{0}$ : Inflasi tidak menyebabkan nilai tukar Rupiah. Berdasarkan kedua hipotesis pada Tabel 5 memberikan kesimpulan bahwa hanya terjadi hubungkan kausalitas satu arah yaitu dari variabel nilai tukar Rupiah terhadap variabel tingkat inflasi.

(3) Hubungan kausalitas jumlah uang beredar dengan nilai tukar Rupiah. Hasil pengujian hubungan kausalitas antara variabel jumlah uang beredar dengan variabel nilai tukar Rupiah disajikan pada Tabel 6 .

Tabel 6. Hasil Uji Kausalitas Jumlah Uang Beredar dengan Nilai Tukar Rupiah

\begin{tabular}{|l|c|l|}
\hline Null Hypothesis & F-Statistic & Kesimpulan \\
\hline $\begin{array}{l}\text { Jumlah uang beredar tidak menyebabkan nilai } \\
\text { tukar Rupiah }\end{array}$ & 2,32426 & Tolak $H_{0}$ \\
\hline $\begin{array}{l}\text { Nilai tukar Rupiah tidak menyebabkan jumlah } \\
\text { uang beredar }\end{array}$ & 3,21208 & Tolak $H_{0}$ \\
\hline
\end{tabular}

Keterangan $F_{0,05 ; 60,120}=1,43$

Berdasarkan hasil pengujian kausalitas granger pada Tabel 6 diperoleh bahwa pada kedua $H_{0}$ nilai F-statistik $>$ dari F-tabel, sehingga $H_{0}$ ditolak dan dapat disimpulkan bahwa terjadi hubungkan kausalitas dua arah baik dari variabel jumlah uang beredar terhadap variabel nilai tukar Rupiah maupun dari variabel nilai tukar Rupiah terhadap variabel jumlah uang beredar. 


\section{Kesimpulan}

Berdasarkan data selama periode Januari 2003 sampai Juli 2018 diketahui terdapat hubungan kausalitas satu arah pada jumlah uang beredar dengan tingkat inflasi dan hubungan kausalitas satu arah pada nilai tukar rupiah terhadap dolar Amerika Serikat dengan tingkat inflasi, serta terdapat hubungan kausalitas dua arah pada jumlah uang beredar dengan nilai tukar rupiah terhadap dolar Amerika Serikat.

\section{Daftar Pustaka}

[1] Agustin, G. 2009. Analisis Paritas Daya Beli pada Kurs Rupiah Terhadap Dolar. JESP. 1(1) : $27-38$

[2] Arifin, T. 2014.Sinergis Sukses Pengusaha \& Bankir. Gramedia Pustaka Utama, Jakarta

[3] Brockwell,P.J. 2016.Introduction to Time Series and Forecasting Third Edition. Springer Nature, Switzerland

[4] Ekananda, M. 2014. Analisis Data Time Series untuk Penelitian Ekonomi, Manajemen dan Akuntansi. Mitra Wacana Media, Jakarta

[5] Gujarati, D. 1999. Ekonometrika Dasar. Erlangga, Jakarta

[6] Hardani, P. R., A. Hoyyi. dan Sudarno 2016. Peramalan Laju Inflasi, Suku Bunga Indonesia dan Indeks Harga Saham Gabungan Menggunakan Metode Vector Autoregressive. Jurnal Gaussian 6(1): $101-110$

[7] Hasoloan, J. 2014. Ekonomi Moneter. CV Budi Utama, Yogyakarta

[8] Rahmawati, A., Di Asih I M. dan A. Hoyyi. 2017. Structural Vector Autoregressive untuk Analisis Dampak Shock Nilai Tukar Rupiah Terhadap Dolar Amerika Serikat pada Indeks Harga Saham Gabungan. Jurnal Gaussian 6(3): $291-302$

[9] Rosadi, D. 2011. Ekonometrika dan Analisis Runtun Waktu Terapan dengan Eviews. Andi, Yogyakarta

[10] Triyono. 2008. Analisis Perubahan Kurs Rupiah terhadap Dollar Amerika. Jurnal Ekonomi Pembangunan 9(2)

[11] Wei, W. W. S. 2006. Time Series Analysis. Addison Wesley, New York 